\title{
Corn supplementation on milk urea nitrogen content of dairy cows grazing on temperate annual pasture
}

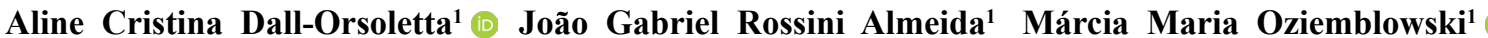 \\ Henrique Mendonça Nunes Ribeiro-Filho ${ }^{*}$ ๑
}

${ }^{1}$ Programa de Pós-graduação em Ciência Animal, Universidade do Estado de Santa Catarina (UDESC), 88520-000, Lages, SC, Brasil. E-mail: henrique.ribeiro@udesc.br. "Corresponding author.

ABSTRACT: The excretion of urinary nitrogen $(N)$, one of the most important environmental contaminants from livestock systems, is highly correlated with milk urea $N$ content. The objective of this research was to evaluate the use of different types of corn supplementation on milk urea $N$ in grazing dairy cows. Twelve Holstein $\times$ Jersey lactating dairy cows were divided into six uniform groups according to milk production, lactation stage and live weight. Treatments were compared according to a $3 \times 3$ replicated Latin square experimental design, with three periods of seventeen days (twelve days to adaptation and five to measurements). The experimental treatments were exclusively grazing (G); grazing + supplementation with $4.2 \mathrm{~kg}$ DM of corn silage (CS) and grazing + supplementation with $3.2 \mathrm{~kg}$ DM of ground corn (GC). The pasture used was annual ryegrass (Lolium multiflorum L.) and white oats (Avena sativa L.). The milk protein production increased $65 \mathrm{~g} /$ day in the GC treatment group compared to the G and CS groups. The supplemented dairy cows showed lower milk urea N (-2.8 mg/dL) than unsupplemented cows, but the $N$ utilization efficiency ( $\mathrm{N}$ output in milk/ $\mathrm{g} N$ intake) did not change between treatments (average $=0.26)$. Additionally, there was a relationship between milk and plasma urea nitrogen concentrations $\left(R^{2}=0.64\right)$. In conclusion, for dairy cows grazing annual temperate pastures, corn ground supplementation increased milk protein production and reduced the excretion of milk urea $N$, whereas corn silage reduced the excretion of milk urea $N$ without affecting milk protein production.

Key words: nitrogen excretion, ground corn, corn silage, grazing.

Efeito da suplementação com grão ou silagem de milho sobre o nitrogênio ureico no leite de vacas em pastos anuais de inverno

RESUMO: A excreção de nitrogênio (N) urinário é um dos mais importantes contaminantes ambientais nos sistemas de produção animal, e possui alta correlação com as concentrações de $N$ ureico no leite. Objetivou-se avaliar a suplementação com grão ou silagem de milho na excreção de $N$ ureico e produção de proteína no leite de vacas em pastos anuais de inverno. Doze vacas em lactação cruza Holandês $\times$ Jersey foram divididas em seis lotes uniformes de acordo com a produção de leite, estádio de lactação e peso vivo. Os tratamentos foram comparados de acordo com um delineamento experimental em duplo Quadrado Latino $3 \times 3$, com três periodos de dezessete dias (doze dias de adaptação e cinco de avaliações). Os tratamentos experimentais foram exclusivamente pastejo (G), suplementação com $4.2 \mathrm{~kg}$ de MS de silagem de milho (CS) e $3.2 \mathrm{~kg}$ de MS de milho moído (GC). O pasto utilizado foi Azevém anual (Lolium multiflorum L.) e Aveia branca (Avena sativa L.). A produção de proteina no leite aumentou $65 \mathrm{~g} /$ dia nos animais do grupo GC quando comparados aos dos grupos $G$ e CS. As vacas suplementadas reduziram os teores de $N$ ureico do leite em comparação às não suplementadas (-2,8 mg/dL), mas a eficiência de uso do $N$ ( $\mathrm{g} N$ produzido no leite/g $N$ ingerido) foi semelhante entre os tratamentos (média $=0,26)$. Além disso, houve uma relação positiva entre as concentrações de $N$ ureico no leite e no plasma $\left(R^{2}=0.64\right)$. Em conclusão, a suplementação com o grão de milho se mostrou eficiente na redução da excreção de $N$ ureico com aumento na produção de proteina do leite, enquanto a silagem de milho permitiu reduções na excreção de $N$ ureico sem afetar a produção de proteina do leite.

Palavras-chave: excreção nitrogênio, milho moído, silagem de milho, pastejo.

Nitrogen (N) deposition on terrestrial ecosystems has increased significantly during the last decades, causing soil acidification, water eutrophication, decreases in biodiversity, and increases in greenhouse gas emissions. The most important gases involved in these processes are ammonia $\left(\mathrm{NH}_{3}\right)$ and nitrous oxide $\left(\mathrm{N}_{2} \mathrm{O}\right)$. A large portion of these gaseous emissions come from animal $\mathrm{N}$ excretion. In mammals, the main form of $\mathrm{N}$ excretion occurs as milk, feces, and urine urea. Following its synthesis, the urea equilibrates rapidly throughout body fluids, including milk and urine. Consequently, studies have shown that is possible to evaluate the urinary $\mathrm{N}$ excretion and $\mathrm{N}$ utilization efficiency using the plasma urea $\mathrm{N}$ and, in practical situations, using the milk urea N (NOUSIAINEN et al., 2004).

The $\mathrm{N}$ utilization efficiency can be affected by the relationship between $\mathrm{N}$ and energy in the diet. In the case of ruminants that are fed fresh forages, ruminal $\mathrm{N}$ losses are often high due to the unbalanced level of high degradable $\mathrm{N}$ and the low fermentable energy in the forage. This leads to an 
inefficient utilization of forage $\mathrm{N}$ to microbial growth, increasing $\mathrm{N}-\mathrm{NH}_{3}$ absorption and urinary $\mathrm{N}$ excretion (PEYRAUD \& DELAGARDE, 2013), which might be mitigated by using supplements containing fermentable carbohydrates, such as ground corn and corn silage. Additionally, it has been shown that energy supply has a role in regulating post-absorptive $\mathrm{N}$ utilization and efficiency by increasing milk protein synthesis (RIUS et al., 2010).

In south Brazil, annual ryegrass and oat are the major fresh forage species used in grazing dairy systems. These species contain high CP and, consequently, energy supplementation may be an alternative to improve the efficiency of forage protein utilization. However, the relationship between feeding strategies commonly used in dairy systems in the south of Brazil and $\mathrm{N}$ excretion needs to be better studied. The aim of this study was to evaluate the effect of corn silage and ground corn supplementation for dairy cows grazing annual temperate pastures on milk urea $\mathrm{N}$ excretion and to quantify the relationship between milk urea $\mathrm{N}$ and plasma urea $\mathrm{N}$ in this condition.

All data presented in this research were measured concomitantly in an experiment in which the objective was to assess the $\mathrm{CH}_{4}$ emissions (DALLORSOLETTA et al., 2019). Thus, a more detailed description of experimental procedures can be reported there. Briefly, the experiment was performed from August to November 2016 in Lages, SC, Brazil $\left(50.18^{\circ} \mathrm{W}, 27.47^{\circ} \mathrm{S} ; 920 \mathrm{~m}\right.$ altitude) in accordance with the regulations of the Santa Catarina State University Ethical Committee (Protocol no. 43.73.09.08.16). Twelve Holstein $\times$ Jersey multiparous cows were separated into 6 homogeneous groups according to milk production $(23.3 \pm 6.9 \mathrm{~kg} / \mathrm{d})$, days in milk (101 \pm 57.6 days), and body weight (492 $\pm 76.8 \mathrm{~kg})$. Each group was randomly assigned to treatment sequences according to a replicated $3 \times 3$ Latin square design. The experimental period lasted 17 days and consisted of 12 days of adaptation and 5 days of measurement. Treatments consisted of cows with access to annual ryegrass + oat without supplementation (G) or with different energy supplementation - ground corn (GC) and corn silage supplementation (CS). The amount of ground corn was limited to $4 \mathrm{~kg}$ / day to avoid drastic modifications on ruminal environment, and the corn silage was calculated to offer the same net energy lactation $\left(\mathrm{NE}_{\mathrm{L}}\right)$ provided by the ground corn supplementation. The $\mathrm{NE}_{\mathrm{L}}$ of supplements was estimated using the equations published by INRA (2007). The quantities offered were 4.2 and $3.6 \mathrm{~kg}$ (as DM basis) of corn silage and ground corn, respectively.
The ryegrass (Lolium multiflorum cv. Barjumbo) and oat (Avena sativa cv. FUNDACEP FAPAR 43) pastures were sown in May 2016 on a total area of 6.5 ha. The area was split into six paddocks, two per treatment, and was grazed by the same two cows during each period. The grazing method was strip grazing, and the herbage allowance (HA) was adjusted to obtain the same post-grazing sward height among treatments. The area allocated daily to each treatment group was calculated by estimating the pregrazing herbage mass (LANTINGA; et al. 2004). The HA above ground level in the G, CS, GC groups were $35,30.8$ and $34.6 \mathrm{~kg} \mathrm{DM} /$ cow/day, respectively.

The cows were milked twice daily (7 a.m. and 3:30 p.m.). Over the last 5 days of each period, individual milk production was recorded, and individual milk samples were collected to determine the milk urea $\mathrm{N}$ concentrations. The herbage DM intake was estimated in each group by determining the difference between the pre- and post-grazing herbage mass values. The milk urea $\mathrm{N}$ was determined by infrared spectrophotometry (Dairy Spect FT, Bentley Instruments Inc, Chaska, Minnesota, USA). The plasma urea $\mathrm{N}$ was determined by individual blood samples. Samples were collected into vacutainer tubes without anticoagulant on the morning of the first (day 13) and last days (day 17) of each experimental period by jugular venipuncture. Tubes were centrifuged $(2,000$ $\times g$ for $10 \mathrm{~min}$ ), and the plasma was then separated and stored at $-20{ }^{\circ} \mathrm{C}$ until it was analyzed for urea.

The ruminal degradable protein (RDP) balance was calculated from the difference between the supply of the truly digestible protein when the degradable nitrogen limits microbial growth (PDIN) and the supply of the truly digestible protein when the available energy limits microbial growth (PDIE) (INRA, 2007). For details about grazed herbage and supplement sampling and analyses see DALL-ORSOLETTA et al. (2019). The CP, NDF and ADF contents of grazed herbage averaged 212, 447 and $236 \mathrm{~g} / \mathrm{kg} \mathrm{DM}$, respectively. The grazed herbage had a good nutritive value; on average, the $\mathrm{NE}_{\mathrm{L}}$ was $1.67 \mathrm{Mcal} / \mathrm{kg} \mathrm{DM}$ and $107 \mathrm{~g}$ of truly protein digestible in the small intestine per $\mathrm{kg}$ of DM. For the corn silage and ground corn, the CP values were 61 and $85 \mathrm{~g} / \mathrm{kg} \mathrm{DM}$, the $\mathrm{NE}_{\mathrm{L}}$ values were 1.53 and $1.82 \mathrm{Mcal} /$ $\mathrm{kg} \mathrm{DM}$, and the truly digestible protein values in the small intestine were 65 and $87 \mathrm{~g} / \mathrm{kg}$ DM, respectively.

The dependent variables were subjected to an analysis of variance using the function PROC MIXED in the software SAS (version 9.3, SAS Institute, Cary, NC, USA) with a model that included the random effect of square, the random effect of cow nested in square, the random effect of period, and the fixed effect of treatment.

The milk production and milk protein production increased in the GC cows compared to 
the $\mathrm{G}$ and CS groups (Table 1). The supplemented dairy cows showed lower milk and plasma urea $\mathrm{N}$ than unsupplemented dairy cows, but the $\mathrm{N}$ utilization efficiency ( $\mathrm{g} \mathrm{N}$ output in milk/g $\mathrm{N}$ intake) did not change between treatments. In a comprehensive review, CASTILLO et al. (2000) showed that N efficiency utilization in dairy cows decreased exponentially when $\mathrm{N}$ intake is greater than $400 \mathrm{~g} /$ day. In the current work, the $\mathrm{N}$ intake of $\mathrm{G}$ and $\mathrm{CS}$ treatments was approximately $400 \mathrm{~g}$ /day, increasing to $482 \mathrm{~g} /$ day in GC cows. Thus, it is logical to assume that cows receiving ground corn supplementation did not reduce $\mathrm{N}$ efficiency utilization because they improved their milk protein production, which was probably a consequence of greater fermentable energy intake. In contrast, cows receiving corn silage had lower metabolizable protein supply but maintained their milk protein production by reducing the $\mathrm{N}$ urinary excretion, as indicated by reductions in milk and plasma urea concentrations when compared to $\mathrm{G}$ cows.
The plasma urea $\mathrm{N}$ concentration recorded in this research was linearly related to the milk urea $\mathrm{N}$ concentration (Figure 1), and both were reduced when the RDP balance was improved (Figure 1b). The relationship between plasma and milk urea $\mathrm{N}$ reflects the rapid equilibration of blood urea into milk, and a positive linear coefficient is expected when values of milk urea $\mathrm{N}$ were not greater than $25 \mathrm{mg} / \mathrm{dL}$ (BURGOS et al., 2007). In the current study, milk urea $\mathrm{N}$ did not exceed $22 \mathrm{mg} / \mathrm{dL}$. Additionally, both corn silage and ground corn supplementation improved the RDP balance, reducing plasma and milk urea $\mathrm{N}$. These results may be, at least partially, explained because temperate herbage grasses are known to have protein contents usually greater than $140 \mathrm{~g} / \mathrm{kg} \mathrm{DM}$, a value that is considered the limit for ruminal nitrogen loss (PEYRAUD \& DELAGARDE, 2013), increasing plasma and milk urea $\mathrm{N}$ concentrations. In this study, the

Table 1 - Dry matter intake, milk production, protein balance, milk and plasma urea $\mathrm{N}$ concentrations of dairy cows grazing annual ryegrass (Lolium multiflorum cv. Barjumbo) and oat (Avena sativa cv. FUNDACEP - FAPAR 43) without supplementation or supplemented with corn silage or ground corn.

\begin{tabular}{|c|c|c|c|c|c|}
\hline Item & G & $\mathrm{CS}$ & GC & SEM & $P$-value \\
\hline \multicolumn{6}{|c|}{ 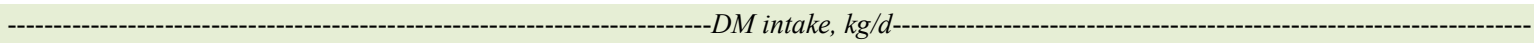 } \\
\hline Herbage & $11.9^{\mathrm{a}}$ & $10.1^{\mathrm{b}}$ & $11.2^{\mathrm{ab}}$ & 0.18 & $<0.001$ \\
\hline Corn silage & - & 3.1 & - & - & - \\
\hline Ground corn & - & - & 3.6 & - & - \\
\hline Total & $11.9^{\mathrm{c}}$ & $13.2^{\mathrm{b}}$ & $14.8^{\mathrm{a}}$ & 0.19 & $<0.001$ \\
\hline Milk production, $\mathrm{kg}$ /day & $21.7^{\mathrm{b}}$ & $21.8^{\mathrm{b}}$ & $23.1^{\mathrm{a}}$ & 0.38 & 0.030 \\
\hline Milk fat, $\%$ & 4.34 & 4.36 & 4.25 & 0.053 & 0.312 \\
\hline Milk protein, $\%$ & $3.13^{\mathrm{b}}$ & $3.07^{\mathrm{c}}$ & $3.21^{\mathrm{a}}$ & 0.020 & $<0.001$ \\
\hline Milk fat, g/day & $931^{\mathrm{b}}$ & $938^{\mathrm{ab}}$ & $974^{\mathrm{a}}$ & 12.7 & 0.056 \\
\hline Milk protein, $\mathrm{g} /$ day & $673^{\mathrm{b}}$ & $662^{\mathrm{b}}$ & $733^{\mathrm{a}}$ & 11.2 & $<0.001$ \\
\hline Crude protein intake, $\mathrm{g} /$ day & $2609^{b}$ & $2498^{b}$ & $3018^{\mathrm{a}}$ & 80.0 & 0.006 \\
\hline PDIN supply, g/day ${ }^{2}$ & $1682^{b}$ & $1387^{\mathrm{c}}$ & $1800^{\mathrm{a}}$ & 37.21 & $<0.001$ \\
\hline PDIE supply, g/day ${ }^{3}$ & $1278^{\mathrm{b}}$ & $1170^{\mathrm{c}}$ & $1518^{\mathrm{a}}$ & 25.35 & $<0.001$ \\
\hline RDP balance, g/day ${ }^{4}$ & $404^{\mathrm{a}}$ & $217^{\mathrm{c}}$ & $282^{\mathrm{b}}$ & 14.56 & $<0.001$ \\
\hline $\mathrm{N}$ efficiency utilization, $\mathrm{g} / \mathrm{g}^{5}$ & 0.266 & 0.269 & 0.251 & 0.006 & 0.140 \\
\hline Milk urea $\mathrm{N}, \mathrm{mg} / \mathrm{dL}$ & $18.1^{\mathrm{a}}$ & $15.2^{\mathrm{b}}$ & $15.4^{\mathrm{b}}$ & 0.37 & $<0.001$ \\
\hline Plasma urea $\mathrm{N}, \mathrm{mg} / \mathrm{dL}$ & $15.4^{\mathrm{a}}$ & $11.9^{\mathrm{b}}$ & $11.2^{\mathrm{b}}$ & 0.51 & $<0.001$ \\
\hline
\end{tabular}

${ }^{1}$ Treatments: G; cows grazing annual ryegrass + oat without supplementation, GC; $4 \mathrm{~kg}$ ground corn supplementation, $\mathrm{CS}$; $15 \mathrm{~kg}$ corn silage supplementation. Means followed by the same letter are not significantly different $(P>0.05)$.

${ }^{2}$ Truly digestible protein when degradable nitrogen limits microbial growth.

${ }^{3}$ Truly digestible protein when available energy limits microbial growth.

${ }^{4}$ Ruminal degradable protein balance.

${ }^{5} \mathrm{~g} \mathrm{~N}$ output in milk/g N intake. 


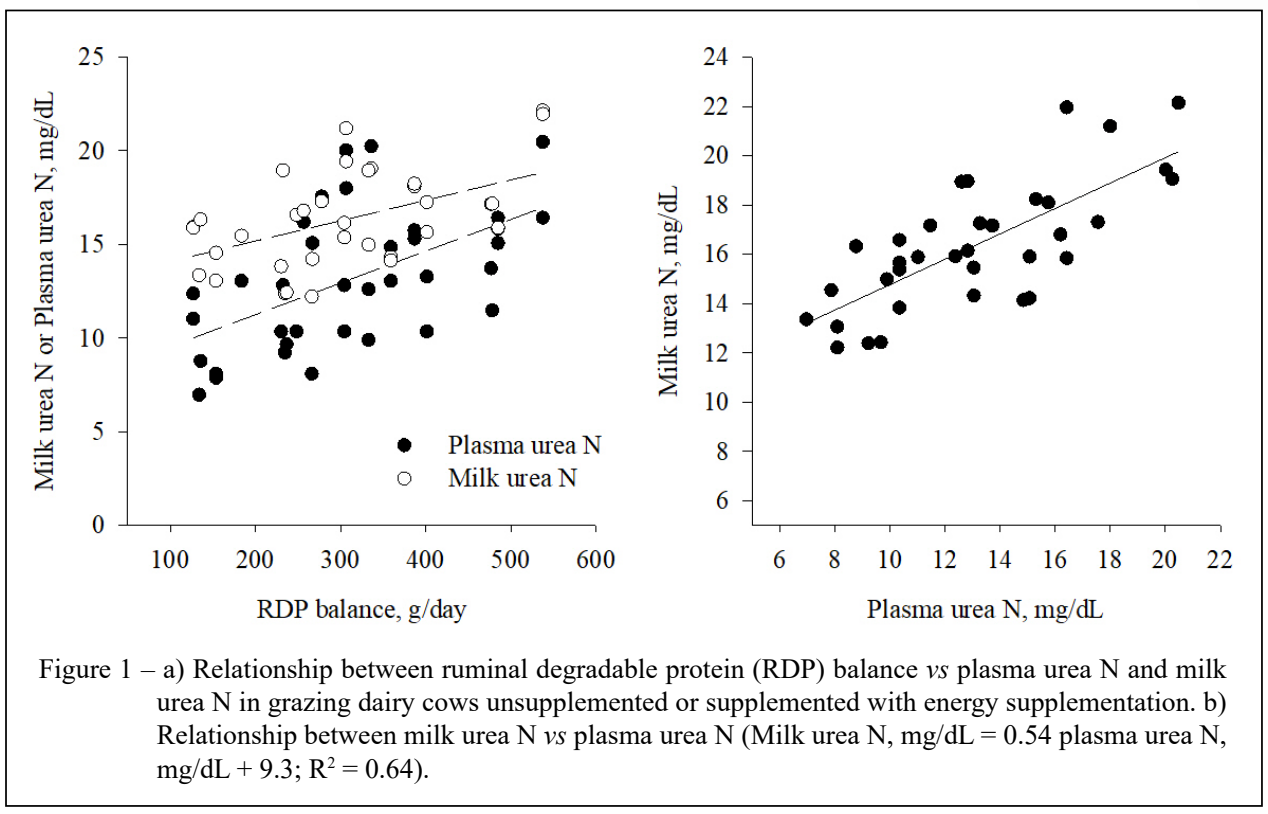

$\mathrm{CP}$ content of the herbage was $210 \mathrm{~g} / \mathrm{kg}$ DM on average, and the RDP balance decreased from 404 to $258 \mathrm{~g}$ /day in the G group when compared to the CS and GC groups.

In conclusion, a moderate level of corn ground supplementation for dairy cows grazing an herbage with good nutritive value was an effective feeding strategy for decreasing the milk urea $\mathrm{N}$ excretion by increasing milk protein production, whereas corn silage supplementation decreased milk urea $\mathrm{N}$ excretion without affecting milk protein production.

\section{ACKNOWLEDGMENTS}

This work was partially supported by Conselho Nacional de Desenvolvimento Científico e Tecnológico - Brasil (CNPq) - Financie Codes 403754/2016-0 and 306313/2016-2, Fundação de Amparo à Pesquisa e Inovação do Estado de Santa Catarina (FAPESC) - Finance Code TR 584 2019, Coordenação de Aperfeiçoamento de Pessoal de Nível Superior - Brasil (CAPES) - Finance Code 001 and Fundo de Apoio à Manutenção e ao Desenvolvimento da Educação Superior - FUMDES, SC - Brasil (Public call n ${ }^{\circ}$ 008/SED/2014).

\section{DECLARATION OF CONFLICT OF INTEREST}

The authors declare no conflict of interest. The founding sponsors had no role in the design of the study; in the collection, analyses, or interpretation of data; in the writing of the manuscript, and in the decision to publish the results.

\section{AUTHORS' CONTRIBUTIONS}

The authors contributed equally to the manuscript.

\section{REFERENCES}

BURGOS, S. A. et al. Prediction of ammonia emission from dairy cattle manure based on milk urea nitrogen: Relation of milk urea nitrogen to ammonia emissions. Journal of Dairy Science, 2007. v.90, p.5499-5508. Available from: $<$ https://doi.org/10.3168/jds.20092415>. Accessed: Jan. 25, 2019. doi: 10.3168/jds.2009-2415.

CASTILLO, A. et al. A review of efficiency of nitrogen utilisation in lactating dairy cows and its relationship with environmental pollution. Journal of Animal and Feed Sciences, 2000. v.9, n.1, p.1-32. Available from: <https://doi.org/10.22358/jafs/68025/2000>. Accessed: Nov. 28, 2018. doi: 10.22358/jafs/68025/2000.

DALL-ORSOLETTA, A. C. et al. Enteric methane emission from grazing dairy cows receiving corn silage or ground corn supplementation. Animal Feed Science and Technology, 2019. v.253, n. May, p.65-73. Available from: <https://doi.org/10.1016/j. anifeedsci.2019.05.009> Accessed: Oct. 28, 2019. doi: 10.1016/j. anifeedsci.2019.05.009.

INRA. Alimentation des bovins, ovins et caprins. Besoins des animaux - valeurs des aliments. Tables Inra 2007. 4. ed. [S.1.]: [s.n.], 2007.NOUSIAINEN, J. et al. Evaluation of milk urea nitrogen as a diagnostic of protein feeding. Journal of Dairy Science, 2004. v.87, p.386-398. Available from: $<$ https://doi.org/10.3168/jds.S00220302(04)73178-1>. Accessed: Apr. 11, 2018. doi: 10.3168/jds.S00220302(04)73178-1.

PEYRAUD, J. L.; DELAGARDE, R. Managing variations in dairy cow nutrient supply under grazing. Animal, 2013. v.7, n.1, p.57-67. Available from: <https://doi.org/10.1017/S1751731111002394>. Accessed: Apr. 11, 2018. doi: 10.1017/S1751731111002394.

RIUS, A. G. et al. Interactions of energy and predicted metabolizable protein in determining nitrogen efficiency in the lactating dairy cow. Journal of Dairy Science, 2010. Available from: $<$ https://doi.org/10.3168/ jds.2008-1777>. Accessed: Jan. 25, 2019. doi: 10.3168/jds.2008-1777. 